\title{
A More Complete Definition for Promiscuous Soybean
} \author{
Phinehas Tukamuhabwa ${ }^{1}$ \\ ${ }^{1}$ College of Agriculture and Environmental Sciences, Makerere University, Uganda \\ ${ }^{2}$ Laboratory of Applied ecology, Faculty of Agronomical Sciences, University of Abomey-calavi, Benin \\ ${ }^{3}$ International Institute of Tropical Agriculture, Zambia \\ ${ }^{4}$ Department of Crop Science, University of Cape Coast, Ghana
}

Eric E Agoyi ${ }^{1,2 *}$, Emmanuel Afutu ${ }^{1,4}$, John Baptist Tumuhairwe ${ }^{1}$, Godfrey Chigeza ${ }^{3}$, Achille E Assogbadjo ${ }^{2}$ and

Submission: January 08, 2018; Published: February 05, 2018

"Corresponding author: Eric Etchikinto Agoyi, College of Agriculture and Environmental Sciences, Makerere University, Uganda, Tel: 0022997989745; Email: ericagoyi@gmail.com

Abstract

Following a series of research on promiscuous nodulation, it came out that it is incomplete to define 'promiscuous soybean' as soybean cultivars with the sole ability to form nodules freely with indigenous Bradyrhizobium strains without requiring the specific type, Bradyrhizobium japonicum. This paper proposes a more complete definition which caters for both nodulation and biological nitrogen fixation ability.

Keywords : Promiscuous soybean; Nodulation; Biological nitrogen fixation; Bradyrhizobium

\section{Context}

Soybean (Glycine max (L.) Merrill) is an annual legume crop, widely grown in tropical, subtropical and temperate regions throughout the world. It accounts for about $84.5 \%$ of the world grain legumes trade [1]. Though soybean is easily introduced in places where it is not native, its production in such places (especially in Africa) is challenged by the lack of Bradyrhizobium japonicum and Sinorhizobium fredii. In fact, soybean belongs to the third group of legumes whereby plants can form nodule effectively with specific strains only. Legumes of this group include: Coronilla, Glycine max, Lens, Leucaena, Lotus, Phaseolus, Pisum, Trifolium Lupinus, Medicago, Melilotus [2]. Being a nodulating legume crop and given its high protein content, soybean plants have a high nitrogen demands to construct an equally high concentration of protein (40\% in soybean grain) [3]. According to Machido et al. [4], soybean crop requires high doses of nitrogen mostly at pod filling stage in order to construct an equally high concentration of grain proteins. It has been reported that soybean requires approximately $80 \mathrm{~kg}$ of nitrogen for each metric tonne of grain yield. For instance, Salvagotti et al. [5] noted that, soybean yielding $5 \mathrm{t} \mathrm{ha}^{-1}$, takes up about $400 \mathrm{~kg}$ of nitrogen. Due to the low available nitrogen in most soils, soybean needs to fix more than half of its nitrogen requirement through biological nitrogen fixation. Salvagotti et al. [5] reported the need for $58 \%$ nitrogen coming from biological $\mathrm{N}_{2}$ fixation.

Bradyrhizobium japonicum and Sinorhizobium fredii are not native in most tropical African soils, Abaidoo et al. [6] reported about $74 \%$ of the African soils having Bradyrhizobium spp. populations which is different from Bradyrhizobium japonicum and do not cause nodulation in most soybean plants. Interstingly, researchers at IITA have found alternative in developing tropical African soybean cultivars. They are meant not to be specific to Bradyrhizobium japonicum, and can easily form nodules with the native Bradyrhizobium strains [7]. Such cultivars are termed 'promiscuous' soybeans. Although they are reffered to as freely nodulating or easily nodulating cultivars, the term promiscuous soybean predominate. Pulver et al. [8] defined promiscuous soybean as soybean cultivars that have the ability to nodulate with indigenous Bradyrhizobium strains. However, nodulation would be useless if not accompanied by sufficient biological nitrogen fixation. Hence we believe the definition needs to be improved to cater for biological nitrogen fixation aspect, as it is the ultimate goal of nodulation.

\section{Definition}

Rather than reffering to the ability to mutiple associations with Bradyrhizobia, promiscuity in soybean rather hints at the ability to form nodules easily or freely with the available Bradyrhizobium and not requiring any specific Bradyrhizobium type. Taking that as reference, Agoyi et al. [9] conducted a series of research ranging from screening of soybean genotypes for promiscuous nodulation Agoyi et al. [9] to assessement of their ability to fix sufficient amount of nitrogen while in symbiotic association with indigenous (non specific) Bradyrhizobium types [10]. 
Based on the fact that all the promiscuous genotypes identified in the studies were capable of fixing substantial amount of nitrogen with both Bradyrhizobium strains used and especially with the indigenous type Bradyrhizobium spp., "promiscuous" soybean cultivars can be best defined as soybean genotypes that have capability to form nodules and fix nitrogen in symbiotic association with one or more indigenous Bradyrhizobium strains, in absence of the specific Bradhyrizobium japonicum. This definition caters for both nodulation and biological nitrogen fixation abilities.

\section{Conclusion}

Promiscuous nodulation in soybean is not merely the ability of soybean plants to form nodules with a more than one soil bacteria type, neither it is sufficient to define it as the sole ability of soybean plants to form nodules with indigenous and readily avialable Bradyrhizobium strains. A complete definition should refer to the ability of soybean plants to forms nodules with indigenous readily available Bradyrhizobium strains, or engage in multiple associations with Bradyrhizobium strains to form nodules and at the same fix a sufficient amount of nitrogen as a result of effectiveness of the population of Bradyrhizobia that colonized the root system. Hence, this paper recommend that before a soybean cultivars be termed as promiscuous, both nodulation ability without requiring the specific type Bradhyrizobium japonicum and nitrogen fixing ability while in symbiotic association with that non specific Bradhyrizobium should be tested.

\section{Acknowledgement}

We are grateful to Intra ACP SHARE, RUFORUM and LEAP Norman Borlaug for their financial supports. Our acknowledgment goes to Dr. Elizabeth Balyejusa Kizito.

\section{References}

1. Abate T, Alene AD, Bergvinson D, Silim S, Orr A, et al. (2011) Tropical legumes in Africa and South Asia: Knowledge and opportunities. TL II Research Report No. 1.

2. Unkovich M, Herridge D, Peoples M, Cadisch G, Boddey R, et al. (2008) Measuring plant-associated nitrogen fixation in agricultural systems. ACIAR Monogr pp. 136-258.

3. Hailu T (2011) Breeding for promiscuous soybeans at IITA, SoybeanMolecular Aspects of Breeding. In: Sudaric A (Eds.), Tech International Institute of Tropical Agriculture (IITA).

4. Machido DA, Olufajo 00, Yakubu SE, Yusufu SS (2011) Enhancing the contribution of the legumes to the $\mathrm{N}$-fertility of soils of the semi-arid zone of Nigeria. African Journal of Biotechnology 10(10): 1848-1853.

5. Salvagotti F, Cassman KG, Specht JE, Walters DT, Weiss A, et al. (2008) Nitrogen uptake, fixation and response to fertilizer $\mathrm{N}$ in soybean: $\mathrm{A}$ review. Field Crops Res 108: 1-13.

6. Abaidoo CR, Keyser HH, Singleton PW, Dulal Borthakur D (2000) Bradyrhizobium spp. (TGx) isolates nodulating the new soybean cultivars in Africa are diverse and distinct from bradyrhizobia that nodulate North American soybeans. International Journal of Systematic and Evolutionary Microbiology 50(1): 225-234.

7. IITA (1996) Understanding nitrogen fixation in promiscuous soybean. In: Microbiology in the service of crops and soils. Annual Report, p. 2023.

8. Pulver EL, Brockman F, Wien HC (1982) Nodulation of soybean cultivars with Rhizobium spp. and their response to inoculation with R. japonicum. Crop Science 22(5): 1065-1070.

9. Agoyi EE, Afutu E, Tumuhairwe JB, Odong TL, Tukamuhabwa P (2016) Screening soybean genotypes for promiscuous symbiotic association with bradyrhizobium strains. African Crop Science Journal 24(1): 4959.

10. Agoyi EE, Afutu E, Chadare FJ, Tumuhairwe JB, Chigeza G, et al. (2017) Ureide essay to assess $\mathrm{n}_{2}$-fixation abilities of soybean genotypes under different bradyrhizobium strains. Journal of Crop Sciences and Biotechnology 20(2): $65-72$.

\author{
Your next submission with Juniper Publishers \\ will reach you the below assets \\ - Quality Editorial service \\ - Reprints availability \\ - Manuscript Podcast for convenient understanding \\ - Global attainment for your research \\ - Manuscript accessibility in different formats \\ ( Pdf, E-pub, Full Text, Audio) \\ - Unceasing customer service
}

- Swift Peer Review

- E-prints Service

Track the below URL for one-step submission https://juniperpublishers.com/online-submission.php 